\title{
Synapse-Associated Protein 90/Postsynaptic Density-95- Associated Protein (SAPAP) is Expressed Differentially in Phencyclidine-Treated Rats and is Increased in the Nucleus Accumbens of Patients with Schizophrenia
}

\author{
Yasuo Kajimoto', Osamu Shirakawa*,', Xian-Hao Lin', Takeshi Hashimoto', Noboru Kitamura², Naoya \\ Murakami $^{3}$, Toru Takumi ${ }^{4}$ and Kiyoshi Maeda' \\ 'Division of Psychiatry and Neurology, Department of Environmental Health and Safety, Kobe University Graduate School of Medicine, Kobe, \\ Japan; '2Department of Psychiatry and Neurology, Kobe General City Hospital, Kobe, Japan; ${ }^{3}$ Department of Psychiatry, Kobe Rosai Hospital, The \\ Labour Welfare Corporation, Kobe, Japan; ${ }^{4}$ Department of Neuroscience, Osaka Bioscience Institute (OBI), Osaka, Japan
}

\begin{abstract}
Phencyclidine (PCP) induces a psychotomimetic state that closely resembles schizophrenia. Therefore, PCP-treated animals can provide a model for schizophrenia. Using differential display, we identified a gene regulated by the delayed action of PCP in rat nucleus accumbens (NAcs). Sequence analysis showed that the cDNA clone obtained was identical to rat synapse-associated protein 90/ postsynaptic density-95-associated protein I (SAPAPI). Quantitative reverse transcriptase (RT)-PCR analysis showed that SAPAPI mRNA had increased significantly in rat NAc $(P<0.000 \mathrm{I})$ and hippocampus $(P<0.0 \mathrm{I}) 24 \mathrm{~h}$ after a PCP $(\mathrm{I} 0 \mathrm{mg} / \mathrm{kg})$ injection as compared to the controls. Immunoquantification using an anti-SAPAPI antibody indicated that immunoreactivity for SAPAPI increased significantly $(P<0.05)$ in the NAcs of unmedicated patients with schizophrenia, as compared to the control subjects and medicated patients with schizophrenia. Our findings support the hypothesis that there is abnormal glutamatergic neurotransmission in schizophrenia and show evidence of abnormalities in the intracellular signal transduction via N-methyl-D-aspartate (NMDA) receptors.

Neuropsychopharmacology (2003) 28, I83 I-1839, advance online publication, 4 June 2003; doi:10.1038/sj.npp. 1300212
\end{abstract}

Keywords: phencyclidine (PCP); differential display; glutamate; NMDA; schizophrenia; brain

\section{INTRODUCTION}

There has been considerable interest in the pathophysiological role of glutamate in schizophrenia (Tamminga, 1998; Meador-Woodruff and Healy, 2000; Goff and Coyle, 2001). Strong evidence that supports an association between glutamatergic dysregulation and schizophrenia has come from pharmacological studies showing that $N$-methyl-Daspartate (NMDA) receptor antagonists, such as phencyclidine (PCP) and ketamine, induce schizophrenia-like symptoms in normal volunteers and exacerbate psychotic symptoms in schizophrenic patients (Luby et al, 1962; Javitt and Zukin, 1991; Krystal et al, 1994; Malhotra et al, 1997;

\footnotetext{
*Correspondence: $\mathrm{Dr} \bigcirc$ Shirakawa, Division of Psychiatry and Neurology, Department of Environmental Health and Safety, Kobe University Graduate School of Medicine, 7-5-I Kusunoki-cho, Chuo-Ku, Kobe 650-00 I7, Japan, Tel: +8I 78382 6065, fax: +8I 783826079 , E-mail: sirakawa@kobe-u.ac.jp

Received OI August 2002; revised 02 January 2003; accepted 23 April 2003

Online publication: 28 April 2003 at http://www.acnp.org/citations/ Npp042802287/default.pdf
}

Lahti et al, 2001). In therapeutic trials, agents that selectively enhance NMDA receptor activity have reduced negative symptoms in schizophrenic patients (Cascella et al, 1994; Javitt et al, 1994; Goff et al, 1995; Heresco-Levy et al, 1996; Rosse et al, 1996). The interpretation of these phenomena suggests that abnormalities in NMDA receptor-mediated signal transduction are associated with the pathophysiology of schizophrenia.

PCP induces a psychotomimetic state that closely resembles schizophrenia. Unlike amphetamine-induced psychosis, PCP-induced psychosis appears to reproduce both schizophrenia-like positive and negative symptoms. It therefore has been used as a model to study the neurochemical mechanisms involved in schizophrenia (Javitt and Zukin, 1991). PCP was developed in the late $1950 \mathrm{~s}$ as a general anesthetic that depressed neither respiration nor circulation. However, up to $50 \%$ of patients given PCP anesthesia developed severe intraoperative reactions characterized by agitation and hallucinations (Javitt and Zukin, 1991). The psychotic state typically lasted 12-96h after administration of PCP but occasionally persisted for 7-10 days (Greifenstein et al, 1958; Meyer 
et al, 1959). Studies have shown that onset of the psychotomimetic effects of PCP is often delayed and that the effects last well beyond peak blood levels of the drug (Meltzer et al, 1972; Wessinger and Owens, 1991). PCP also has other delayed actions. Olney et al (1989) reported intracellular vacuolization in the rat posterior cingulate and retrosplenial cortex after administration of PCP. Gao et al, reported its dose-sensitive, delayed action on regional cerebral glucose metabolism of the rat, which occurred over $48 \mathrm{~h}$, and a late (at $24 \mathrm{~h}$ ) change in NMDA and kainate binding in the hippocampal areas (Gao et al, 1993; Gao and Tamminga, 1994; Gao and Tamminga, 1996). Okuyama et al (1995) found that PCP produced delayed cognitive dysfunction (at $24 \mathrm{~h}$ ) in rats subjected to water maze tasks. These delayed actions of PCP provide information about the mechanism of PCP-induced psychosis, and possibly, about the neurochemical pathophysiology of schizophrenia.

Recently, mRNA differential display has provided a powerful means of identifying and cloning differentially expressed genes (Liang and Pardee, 1992). We used this method to identify a gene in rat nucleus accumbens (NAcs) that is regulated by the delayed PCP actions. The NAc, the terminal projection site of the mesolimbic dopamine system, is speculated to be critical to the etiology of schizophrenia and critical to reinforcing the properties of drug abuse (Chambers et al, 2001). The NAc has been postulated to be important in schizophrenia because all clinically effective antipsychotics have been known to interfere with dopamine transmission in this region (O’Donnell and Grace, 1998).

Using this approach, we identified synapse-associated protein 90/postsynaptic density-95-associated protein 1 (SAPAP1) (Takeuchi et al, 1997) and found increased SAPAP1 mRNA in rat NAc $24 \mathrm{~h}$ after PCP was administered as well as increased SAPAP1 immunoreactivities in the NAcs of patients with schizophrenia. SAPAP/guanylate kinase-associated protein (GKAP) (Kim et al, 1997)/ hDLGand PSD-95-associated protein (DAP) (Satoh et al, 1997) form a family of proteins that are highly concentrated in the postsynaptic density (PSD) and bind to the guanylate kinase (GK) domain of PSD-95. For simplicity, we here refer to SAPAP/GKAP/DAP as SAPAP. This is the first study to examine the contribution of SAPAP1, one of the NMDA receptor-mediated intracellular signal proteins, to the pathophysiology of schizophrenia.

\section{METHODS}

\section{Materials}

PCP $\mathrm{HCl}$ was a gift from Yamanouchi Pharmaceuticals Ltd (Osaka, Japan). Haloperidol decanoate was obtained from Dainippon Pharmaceuticals Co., Ltd (Osaka, Japan). Peroxidase-linked anti-rabbit or mouse Ig (from the donkey) and the enhanced chemiluminescence Western blot detection system were obtained from Amersham (Buckinghamshire, UK), and molecular weight standards from Bio-Rad Laboratories (Richmond, CA). Polyvinylidene difluoride membranes (pore size; $0.45 \mu \mathrm{m}$ ) were purchased from Millipore (Bedford, MA). All other chemicals used were of analytical grade and obtained from commercial sources.

\section{Animals and Treatments}

All experiments were conducted according to the Ethical Guidelines for Animal Experimentation at Kobe University Graduate School of Medicine. Male Sprague-Dawley (SD) rats (300-350 g, CLEA Japan Inc., Tokyo, Japan) were used. The animals were kept in a controlled environment with $12 \mathrm{~h}$ dark-light cycles and free access to food and water. For the mRNA differential display and quantitative RT-PCR analyses, rats were acclimated to their surroundings and given a single subcutaneous injection of $\mathrm{PCP} \mathrm{HCl}(10 \mathrm{mg} / \mathrm{kg}$, diluted in sterile saline) or an equal volume of sterile saline. They were decapitated $24 \mathrm{~h}$ later, and their brains were rapidly removed. The NAc, anterior cingulate cortex, hippocampus, and caudate-putamen were excised from 1.5-mm-thick coronal cross-sections of the brain with a syringe needle, diameter $1.5 \mathrm{~mm}$, as described by Palkovits (1973). Tissues were stored at $-80^{\circ} \mathrm{C}$ until used.

To examine the effects of neuroleptics, rats were given an intramuscular injection of haloperidol decanoate $(30 \mathrm{mg} / \mathrm{kg})$ or the oil vehicle. At 21 days after injection, the rats were killed, and their NAcs excised.

\section{mRNA Differential Display}

The RNA image $^{\mathrm{R}}$ protocol and kit from GenHunter (Brookline, MA) were used for the mRNA differential display. Isolation of total RNA from rat NAc was carried out with the TRIzol ${ }^{\mathrm{R}}$ Reagent (Gibco, BRL). Total RNA (each $0.5 \mu \mathrm{g}$ ) was converted to cDNA by the use of Maloney murine leukemia virus (MMLV), reverse transcriptase (RT), and an oligo (dT) primer.

One-tenth of the cDNA was amplified in a $20 \mu \mathrm{l}$ total reaction volume containing $1 \times$ PCR buffer $(10 \mathrm{mM}$ Tris$\mathrm{HCl}, 1.5 \mathrm{mM} \mathrm{MgCl} 2, \mathrm{pH} 9.0$ ), $20 \mathrm{pmol}$ of the oligo (dT) primer (T12MN), 4 pmol of an arbitrary hexamer primer, $2 \mu \mathrm{M}$ dNTP, and $1 \mathrm{U}$ Taq DNA polymerase (Amplitaq Gold ${ }^{\mathrm{R}}$; Perkin-Elmer, Norwalk, CT). Cycling parameters were $94^{\circ} \mathrm{C}$ for $1 \mathrm{~min}, 40^{\circ} \mathrm{C}$ for $2 \mathrm{~min}$, and $72^{\circ} \mathrm{C}$ for $1 \mathrm{~min}$ for 40 cycles, then $72^{\circ} \mathrm{C}$ for $7 \mathrm{~min}$. The amplified cDNAs were separated in a $6 \%$ DNA sequence gel, after which the gel was stained with $\mathrm{SYBR}^{\mathrm{R}}$ Green II nucleic acid gel stain (Molecular Probes, Eugene, OR).

Bands representing differentially expressed cDNAs were excised from the gel, reamplified by a PCR with the same primers, and subcloned into the pCR II vector (Invitrogen, San Diego, CA) by TA cloning. Inserts were analyzed by supercoil dideoxynucleotide sequencing.

\section{cDNA Cloning}

A rat brain cDNA library (Uni-ZAP XR Library, Stratagene, La Jolla, CA) was screened with ${ }^{32} \mathrm{P}$-labeled DNA probes from subcloned PCR-derived fragments to isolate fulllength cDNA clones. Approximately $5 \times 10^{5}$ clones were screened, and three positive clones obtained. DNA was sequenced by the dideoxynucleotide termination method in an Applied Biosystems Prism (ABI PRISM) 377 DNA sequencer (Perkin-Elmer). 
Table I Autopsy and Clinical Data

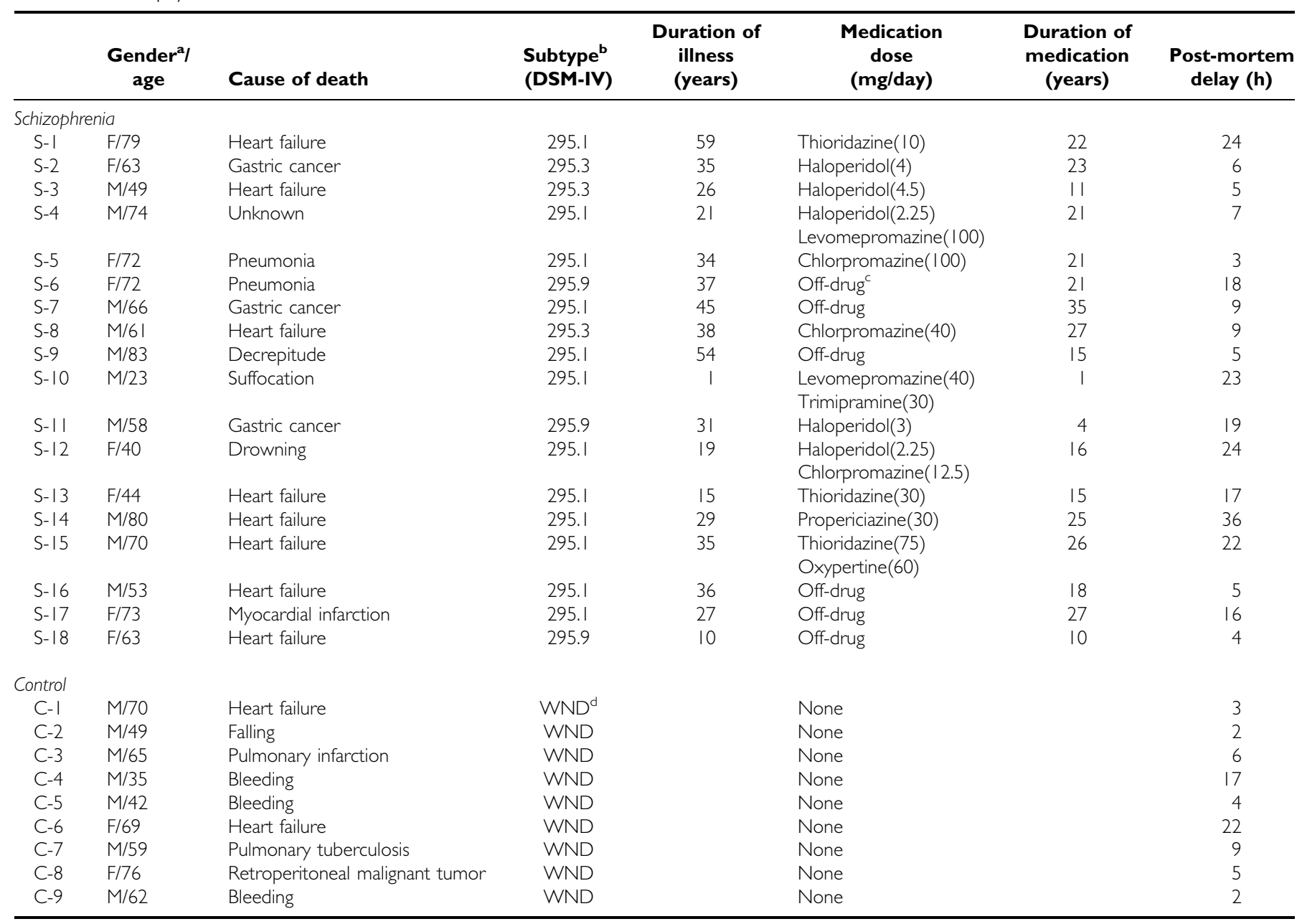

a, male; $F$, female.

b295. I, disorganized type; 295.3, paranoid type; 295.9, undifferentiated type.

'Off-drug, no neuroleptic treatment for at least 3 months before death.

'WND, without neuropsychiatric disease.

\section{Quantitative RT-PCR}

Quantitative RT-PCR was carried out with real-time TaqMan technology (Heid et al, 1996), and the analysis was carried out with an ABI PRISM 7700 (Perkin-Elmer). The method measures PCR product accumulation by use of a dual-labeled fluorogenic probe (the TaqMan probe). The fluorescent reporter FAM (6-carboxyl-fluorescein) located on the $5^{\prime}$ end of the probe is released from a quencher dye (TAMRA, 6-carboxyl-tetramethyl-rhodamine) present on the $3^{\prime}$ end. The total RNA extracted by TRIzol from the rat NAc, anterior cingulate cortex, hippocampus, and caudateputamen was digested with DNase RQI (Promega). Primers were made from sequences of the isolated clone which corresponded to the $3^{\prime}$-noncoding region of SAPAP1. Sequences of the specific primers were forward: $5^{\prime}$ CGATACAGCCTGTTACCCACTG-3'; reverse: $5^{\prime}$-TTGATGAGGGAGACAAACTTCTT- $3^{\prime}$; and the TaqMan probe: $5^{\prime}$ AAACTGACAGCGGGAACCTTTATTGCGTT- $3^{\prime}$. Amplification reactions $(50 \mu \mathrm{l})$ contained an RNA sample $(250 \mathrm{ng}$ each); $5 \times$ TaqMan EZ Buffer; $300 \mu \mathrm{M}$ dATP, dGTP, and dCTP; $600 \mu \mathrm{M}$ dUTP; $4 \mathrm{mM} \mathrm{MgCl}_{2} ; 5 \mathrm{U}$ rTth DNA poly- merase; $0.5 \mathrm{U}$ AmpErase uracil N-glycosylase (UNG); and $200 \mathrm{nM}$ each of the forward and reverse primers and $100 \mathrm{nM}$ TaqMan primer. Thermal cycling was done for 50 cycles of $95^{\circ} \mathrm{C}$ for $15 \mathrm{~s}$ and $60^{\circ} \mathrm{C}$ for $45 \mathrm{~s}$. As the internal control for the RNA, GAPDH expression was examined under the same conditions. Ratios of SAPAP1 to GAPDH were calculated and normalized.

\section{Human Brains}

Brains were obtained at autopsy from 18 right-handed Japanese patients with schizophrenia (10 men, eight women, mean age $=62.4$ years, $S D=15.7)$ and nine right-handed control subjects (seven men, two women, mean age $=58.6$ years, $S D=13.8$ ) who were without any history of neuropsychiatric disorders (Table 1). Consent was obtained from close relatives of the control and schizophrenic patients after the purpose and procedures of our research had been fully explained. The mean post-mortem delay was $14.0 \mathrm{~h}(\mathrm{SD}=9.4)$ for the patients and $7.8 \mathrm{~h}(\mathrm{SD}=7.1)$ for the controls. There was no significant difference between the 
two groups with respect to age or the time from death to autopsy (Mann-Whitney $U$ test). None of the schizophrenic patients had undergone remission in spite of having been given psychiatric treatment, and before death all had manifested schizophrenic symptoms. The schizophrenia diagnoses corresponded to the DSM-IV category (American Psychiatric Association, 1994). In all, 12 patients had received neuroleptics just prior to death, whereas six had had no medication for at least 3 months before death.

\section{Antibody}

Rat polyclonal antibody to SAPAP1, raised in rabbits against a GST fusion of SAPAP1 residues 589-689, was a gift from Dr Y Takai (Department of Molecular Biology and Biochemistry, Osaka University Medical School, Japan). Antibody against $\beta$-actin was purchased by Adcam Ltd (Cambridge, UK).

\section{Tissue Preparation and Western Blot Analysis}

At autopsy, brains were excised as described elsewhere (Nishino et al, 1986). Briefly, they were removed and stored at $-80^{\circ} \mathrm{C}$. Next, they were cut into coronal blocks $1 \mathrm{~cm}$ thick on dry ice to obtain tissue blocks. The NAcs were then excised and stored at $-80^{\circ} \mathrm{C}$ until use. About $1 \mathrm{~g}$ of tissue block was homogenized in 10 volumes of ice-cold $50 \mathrm{mM}$ Tris- $\mathrm{HCl}$ buffer ( $\mathrm{pH} 7.4$ at $25^{\circ} \mathrm{C}$ ) containing $1 \mathrm{mM}$ EDTA, $5 \mathrm{mM}$ EGTA, $20 \mathrm{U} / \mathrm{ml}$ aprotinin, $20 \mu \mathrm{g} / \mathrm{ml}$ antipain, $20 \mu \mathrm{g} / \mathrm{ml}$ leupeptin, $10 \mu \mathrm{M} \quad N$-acetyl-LEU-LEU-norleucinal, $1 \mathrm{mM}$ phenylmethylsulfonyl fluoride, and $25 \mathrm{mM}$ 2-mercaptoethanol. The homogenates were used in the Western blot analysis.

Rat brain samples were homogenized in the same buffer used for the human brain samples. Protein contents of the samples were determined by the method of Lowry et al (1951) with bovine serum albumin as the standard.

Samples $(20 \mu \mathrm{g}$ protein/lane for SAPAP $1 ; 5 \mu \mathrm{g}$ protein/ lane for $\beta$-actin) were fractionated in a sodium dodecyl sulfate/polyacrylamide gel (SDS-PAGE) $(7.5 \%$ gel for SAPAP $1 ; 15 \%$ gel for $\beta$-actin) by the method of Laemmli (1970), transferred to a polyvinylidene difluoride membrane, and the whole membrane was incubated for $90 \mathrm{~min}$ at room temperature with specific antibodies for SAPAP1 diluted 1:1000. Immunoreactive bands were made visible by an enhanced chemiluminescence Western blot detection system and scanned with a Scanjet 3c scanner (HewlettPackard Co., Greeley, CO). Densitometric readings made with a computer program (NIH Image version 1.59) were confirmed as being within the linear range by processing blots with various concentrations $(1-10 \mu \mathrm{g}$ protein) of the same control sample at the time of the assay. Densitometric readings of the immunoblots on the membranes were normalized by this standard line. Values were expressed as percentages of the mean values for the control subjects. All determinations were performed in triplicate.

\section{Statistics}

A two-tailed Student's t-test was used to estimate the significance of immunoreactivity difference between the two groups. The significance of differences among the three groups was tested by an analysis of variance (ANOVA) and, if significant, Fisher's Protected Least Significant Difference (Fisher's PLSD) was applied.

\section{RESULTS}

\section{Differential Display and cDNA Cloning}

mRNA expression $24 \mathrm{~h}$ after the PCP injection was analyzed by differential display PCR. As compared with the controls, three cDNA fragments had greater amplification in rat NAc after PCP injection. One clone, PRP2, was analyzed further (Figure 1). The cDNA fragment was isolated from a preparative acrylamide/urea gel, subjected to PCR under standard conditions, then subcloned into the pCRII vector via TA cloning. The nucleotide sequence of the clone was AT-rich, which is indicative of a $3^{\prime}$-untranslated region. A sequence homology search with the BLAST program showed that it had the highest homology $(96.8 \%$ for the nucleotide sequences) to human chromosome 18pterp11.23 clone 34 mRNA (Yoshikawa et al, 1997), a human EST.

To obtain cDNA that had the coding region of the PRP2 gene, a rat brain cDNA library was screened with the radiolabeled PRP2 fragment as the probe, and a cDNA fragment of $\sim 1.4 \mathrm{~kb}$ was obtained. A homology search of the databases showed that this cDNA clone was identical to

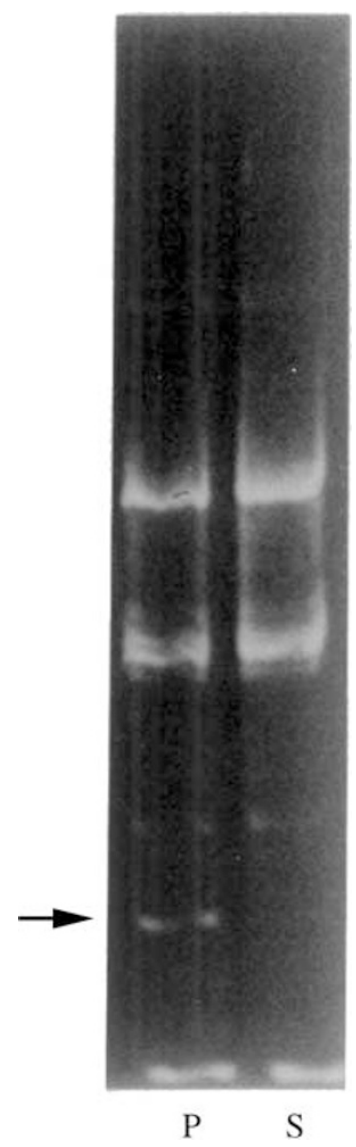

Figure I PCR differential display analysis of rat brain mRNA $24 \mathrm{~h}$ after a PCP (P) or saline (S) injection. A portion of a typical gel is shown. Differential display was carried out as described in Methods. The arrow indicates the high level band present in the PCP-treated sample lane. 
rat SAPAP1. Therefore, we concluded that it encoded rat SAPAP1.

\section{Quantitative RT-PCR}

The results of differential display were confirmed by quantitative RT-PCRs performed on a large number of rat brains to exclude the possibility that the differentially displayed fragments found represent artifacts sometimes present in differential display applications (Liang and Pardee, 1995). Using real-time TaqMan technology (Heid et al, 1996), we estimated the SAPAP1 mRNA in the NAc, anterior cingulated cortex, caudate putamen, and hippocampus of two matched groups of PCP-treated $(n=3)$ and control $(n=3)$ rats. SAPAP1 expression was measured by the RT-PCR method with an ABI PRISM 7700 (PerkinElmer), as described in Methods. As a reference, GAPDH from the same RNA samples was measured. The expression value calculated for SAPAP1 divided by that for GAPDH was normalized. Results are expressed as percentages of the values obtained from control rats taken as $100 \%$ (Figure 2). At $24 \mathrm{~h}$ after the PCP administration, SAPAP1 expression in the NAc and hippocampus were 51 and $13 \%$ higher than the expression in the control $(P<0.0001$ and $P<0.01$, respectively). SAPAP1 expression in the caudate-putamen was increased by $18 \%$, but the difference was not significant. In the anterior cingulate cortex, no such alteration was found. Western blot analysis using a polyclonal antibody to SAPAP1 indicated that, $24 \mathrm{~h}$ after the PCP injection, SAPAP1 immunoreactivity in the rat NAc did not differ significantly from the controls (data not shown).

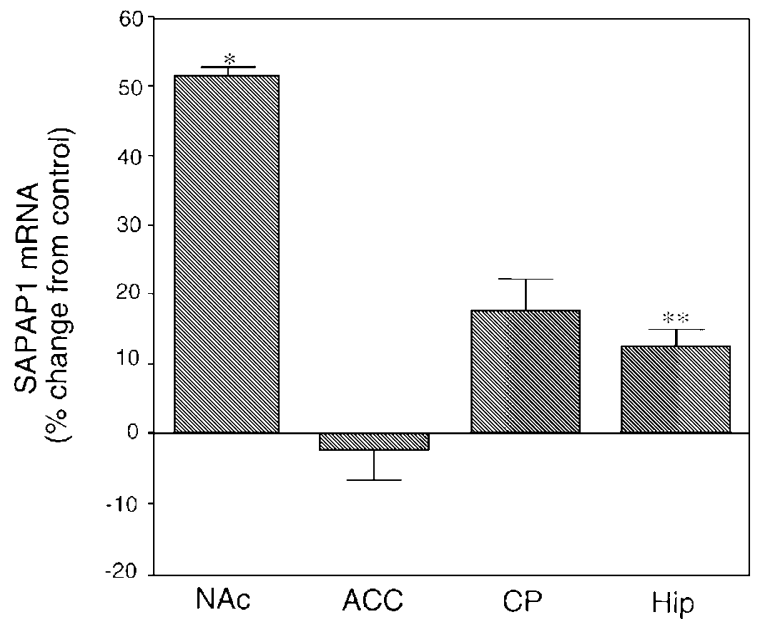

Figure 2 Quantitative PCR of SAPAPI expression 24h after a PCP injection as compared to the controls. SAPAPI expression was measured by the RT-PCR method using the ABI PRISM 7700 (Perkin-Elmer) as described. After examining the amplification plot and standard curve, RNA samples $(50 \mu \mathrm{g})$ from several tissues after a PCP or saline injection were tested. For references, GAPDH was measured from the same samples. Ratios of SAPAPI to GAPDH were calculated. The calculated expression level of SAPAPI after PCP administration divided by that of controls was normalized to 100. Results are expressed as a percentage of the control values taken as $100 \%$ and are shown as means \pm SD $(n=3)$. Significant differences between the two groups were assessed by means of two-tailed Student's $t$-test $(* P<0.0001, t=66.91, \mathrm{df}=4$; $* * P<0.01, t=5.34, \mathrm{df}=4)$. NAc: nucleus accumbens; ACC: anterior cingulate cortex; CP: caudateputamen; Hip: hippocampus.

\section{Immunoquantification of SAPAP1 in the NAc of Patients with Schizophrenia Using Specific SAPAP1 Antisera}

Consistent with the results of the differential display method, quantitative RT-PCR analysis showed that SAPAP1 in the NAc was regulated by the delayed action of PCP. SAPAP1 immunoreactivity was measured in the brains of patients with schizophrenia to examine whether it is involved in the neurochemical pathogenesis of schizophrenia, by Western blot analysis with specific polyclonal antisera against SAPAP1.

Figure 3 shows representative immunoblots with antibody against SAPAP1 in NAcs from control subjects and schizophrenic patients. The most prominent band was at $140 \mathrm{kDa}$, which is consistent with the size found in the rat brain by Takeuchi et al (1997). A faint band of $\sim 100 \mathrm{kDa}$ may represent a different transcript of SAPAP1, DAP1 $\beta$ / GKAP, by alternative splicing. A polyclonal antibody to SAPAP1 was raised against a peptide consisting of aminoacid residues 589-689 of the rat SAPAP1 sequence. The amino-acid sequence of residues $589-689$ in rat is $89.1 \%$ identical to that of human DAP1 $/ /$ SAPAP1, suggesting that the antigenicity of SAPAP1 in rat and human brains do not differ much.

In the NAcs of patients with schizophrenia, the immunoreactivity for SAPAP1 was $10.1 \%$ higher than that of the age-matched controls (Figure 4). The patients with schizophrenia could be divided into two groups: a 'medicated' group that had been on neuroleptics at the time of death and an 'unmedicated' group that had not been on

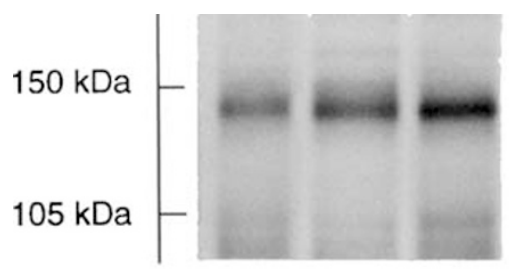

SAPAP 1

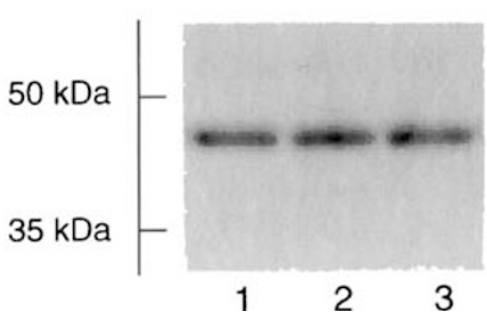

$\beta$-actin

Figure 3 Representative immunoreactive bands for the control subjects and schizophrenic patients determined with antibodies against SAPAPI and $\beta$-actin. Patients were divided into two groups: 'medicated', those who had been on neuroleptics at the time of death; 'unmedicated', those who had not been on neuroleptics for 3 months or more before death. Samples ( $20 \mu \mathrm{g}$ protein/lane for SAPAPI; $5 \mu \mathrm{g}$ protein/lane for $\beta$-actin) of NAcs of the control subjects and schizophrenic patients were fractionated in SDSPAGE $(7.5 \%$ gel for SAPAPI; 15\% gel for $\beta$-actin). Proteins were transferred to a polyvinylidene difluoride membrane, incubated with the specific antibodies, and made visible by an enhanced chemiluminescence Western blot detection system. Molecular sizes $(\mathrm{kDa})$ of marker proteins are given on the left. The immunoreactive bands for SAPAPI and $\beta$-actin were detected at $\sim 140$ and $\sim 42 \mathrm{kDa}$, respectively. Lane I, control subject; lane 2, medicated patient with schizophrenia; lane 3, unmedicated patient with schizophrenia. 


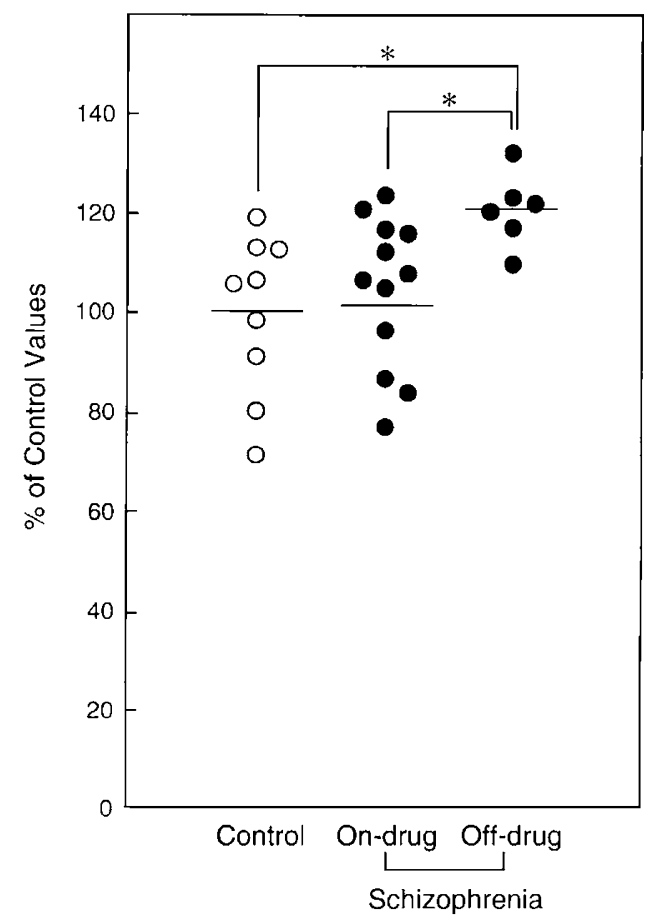

Figure 4 Scattergrams of SAPAPI immunoreactivities in NAcs of the control subjects, and medicated and unmedicated patients with schizophrenia. Results are shown as percentages of the control values. Significant differences in the amounts of SAPAPI immunoreactivities were observed among the groups by means of ANOVA $(F=4.13, d f=2,24, P=0.029)$, followed by Fisher's PLSD $(* P<0.05)$.

neuroleptics for 3 months or more before death. In the unmedicated patients, immunoreactivity of SAPAP1 was $21.0 \%$ higher than in the controls $(P=0.010)$. In the medicated patients, SAPAP1 did not differ significantly from the value for the controls. There was, however, a significant difference $(P=0.031)$ in SAPAP1 immunoreactivity between the 12 medicated and six unmedicated patients with schizophrenia. Furthermore, there were no significant changes in the amounts of $\beta$-actin between the control subjects and the schizophrenic patients, suggesting that the above-mentioned significant changes indicate a modification of the SAPAP1 immunoreactivity itself. No significant correlation was found between SAPAP1 immunoreactivity and time after death to autopsy $(P>0.05$, Spearman's rank order correlation).

\section{Effect of Neuroleptics on SAPAP1 Immunoreactivity in Rat Brain}

Rats were injected intramuscularly with haloperidol decanoate $(30 \mathrm{mg} / \mathrm{kg})$ or an oil vehicle to examine the effect of a neuroleptic. SAPAP1 immunoreactivity in the rat NAc was affected by haloperidol decanoate treatment (after 21 days). SAPAP1 decreased by $18.4 \%(P=0.008)$, in rats treated with the neuroleptic as compared with the controls (Figure 5).

\section{DISCUSSION}

We used mRNA differential display to identify genes whose transcript levels are regulated by the delayed action of PCP. A candidate cDNA fragment was isolated and sequenced. It

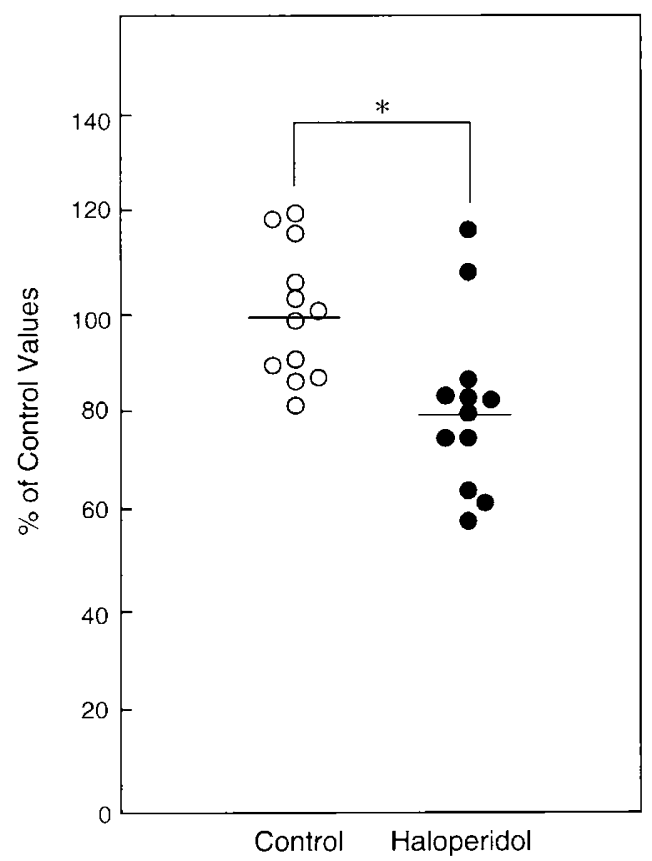

Figure 5 Effect of haloperidol decanoate treatment on SAPAPI immunoreactivities in rat NAcs. SD rats were injected intramuscularly with haloperidol decanoate $(30 \mathrm{mg} / \mathrm{kg})$ or an oil vehicle. At 21 days after injection, all the rats were killed, and their NAcs excised. Tissue preparation and immunoquantification of SAPAPI were carried out as described in Methods. Results are expressed as percentages of the control values. Significant difference in the amounts of SAPAPI immunoreactivities were observed between the two groups (two-tailed Student's $t$-test, $t=2.92$, $\mathrm{df}=22, * P<0.01)$.

carried a $3^{\prime}$-untranslated region and had very close homology to human chromosome 18pter-p11.23 clone 34 mRNA (Yoshikawa et al, 1997). Subsequent screening of a cDNA library showed that it is identical to rat SAPAP1.

SAPAPs (also called GKAP or DAP), a family of proteins identified recently, are expressed in the brain and are highly concentrated in the PSD (Takeuchi et al, 1997; Kim et al, 1997; Satoh et al, 1997). The PSD is a specialized structure beneath the postsynaptic membrane and is crucial to the structural and functional organization of the postsynaptic neurotransmitter receptor proteins and to the adhesion of the postsynapse to presynaptic terminals (Ziff, 1997). Studies in various laboratories over the past 10 years have identified a number of novel proteins that are part of the PSD. The PSD-95 family of membrane-associated guanylate kinases (MAGUK) have critical roles at the postsynaptic sites of glutamatergic synapses due to their interactions with a variety of ion channels, receptors, cytoskeletal components, and intracellular signaling proteins (Ziff, 1997; Sheng and Wyszynski, 1997; Craven and Bredt, 1998; Kennedy, 1998; O'Brien et al, 1998). Members of this protein family (PSD-95/SAP90, SAP97/hdlg, PSD-93/chapsyn-110, and SAP102) have a common domain organization of three PDZ domains, an Src homology 3 (SH3) domain, and a GK domain (Scannevin and Huganir, 2000). Of these proteins, PSD-95, SAP102, and PSD-93 interact directly with the carboxyl termini (C-termini) of specific NMDA receptor subunits (NMDAR2A and NMDAR2B) both in vitro and in vivo, and induce the clustering of NMDA receptors (Kornau et al, 1995; Lau et al, 1996; Niethammer et al, 1996). These 
findings indicate that MAGUK proteins may be essential for NMDA receptor clustering at synapses (Scannevin and Huganir, 2000).

The SAPAP protein family has at least four members and undergoes complex alternative splicing, but the physiological roles of its members are unknown (Takeuchi et al, 1997; Kim et al, 1997; Satoh et al, 1997). SAPAP interacts with the GK domains of PSD-95 via the middle region that carries five repeats of 14 amino acids. SAPAP also binds Shank (Naisbitt et al, 1999)/synamon (Yao et al, 1999) via the Cterminal region. Shank directly interacts with SAPAP and Homer and potentially can bridge the NMDA receptor-PSD95-SAPAP and metabotropic glutamate receptor-Homer complexes in synapses (Naisbitt et al, 1999; Tu et al, 1999). Thus, SAPAPs are thought to be important in the recruiting and clustering of NMDA receptors and MAGUKbased signaling complexes.

In our study, SAPAP1 was drastically increased in the NAc, and slightly, but significantly, increased in the hippocampus due to delayed PCP action. PCP is thought to block the ion channel in the NMDA receptor complex, resulting in diminished glutamatergic neurotransmission at that receptor complex. Increased expression of SAPAP1 mRNA after PCP treatment may reflect upregulation of SAPAP1 induced by blockade of the NMDA receptor. At a high dose, PCP not only has an effect at the NMDA receptor complex but also other neurochemical effects. The mechanism by which SAPAP1 is increased in the NAc and hippocampus after PCP remains unclear, but changes in the larger neurochemical network in addition to altered glutamatergic transmission may contribute to its mechanism. In contrast, haloperidol decanoate treatment significantly decreased SAPAP1 in the NAc. Antipsychotic drugs could affect glutamatergic neurotransmission by modulating the release of glutamate, by interacting with glutamate receptors, or by altering the density or subunit composition of glutamate receptors (Goff and Coyle, 2001). Chronic neuroleptic administration increases the extracellular glutamate concentration in the NAc (Yamamoto and Cooperman, 1994). A recent study found that antipsychotic drugs facilitate NMDA receptor activity by means of an intracellular mechanism (Leveque et al, 2000). Decreased SAPAP1 immunoreactivity in NAc's of rats treated with haloperidol decanoate may reflect an adaptive or compensatory reaction of SAPAP1 to NMDA receptor activation. These findings suggest that SAPAPs may be important in the regulation of glutamatergic neurotransmission via NMDA receptors.

Glutamatergic dysfunction has been suggested to be the basis of the pathophysiology of schizophrenia (Tamminga, 1998; Meador-Woodruff and Healy, 2000; Goff and Coyle, 2001), but it is not clear whether glutamatergic hypofunction results from a primary defect in NMDA receptors or from a defect in one component of NMDA receptormediated intracellular signal transduction. Despite the hypothesis that glutamatergic dysfunction in schizophrenia involves the NMDA receptor, relatively few studies have been made of this receptor subtype. Available findings for the NMDA receptor vary markedly, but a consistent feature is that in schizophrenia the obligated NMDAR1 subunit is expressed abnormally in some cortical regions (MeadorWoodruff and Healy, 2000). Few studies have been conducted on the downstream area of the NMDA receptor in brains of schizophrenic patients, but some studies have examined the expression of PSD-95 mRNA in the schizophrenic brain. In situ hybridization analysis showed that PSD-95 expression in the prefrontal cortex was significantly decreased in post-mortem material obtained from neuroleptic-treated schizophrenics (Ohnuma et al, 2000). Another study conducted with quantitative real-time RT-PCR found significantly high mRNA expression of PSD-95 in the occipital cortex of schizophrenic patients (Dracheva et al, 2001).

In our study, immunoreactivity for SAPAP1 was increased significantly in the NAcs of unmedicated patients with schizophrenia. This suggests that the organizing signaling cascades in the NAcs of patients with schizophrenia may be abnormal and that antipsychotics might reverse this abnormality. Our findings support the hypothesis that there is abnormal glutamatergic neurotransmission in schizophrenia. Moreover, they provide evidence of a potential mechanism by which SAPAPs may govern the pathophysiology of schizophrenia, as well as the neurochemical mechanisms of antipsychotics.

Furthermore, the human SAPAP1 gene is located on chromosome 18p11, which has been linked to both schizophrenia and bipolar disorder (Berrettini et al, 1994; Stine et al, 1995; Schwab et al, 1998; Detera-Wadleigh et al, 1999; Nothen et al, 1999). Berrettini (2000) hypothesized that schizophrenic and bipolar syndromes share certain genetic risk factors and that chromosome $18 \mathrm{p} 11$ is one of four genomic regions of overlap for schizophrenic and bipolar susceptibility loci. These findings suggest that SAPAPs are candidate gene sources for schizophrenia.

The study of SAPAP and its relatives promises to increase our understanding of the role of glutamate in the pathophysiology of schizophrenia. Further study is needed for the functional analysis of the human SAPAP gene in patients with schizophrenia.

\section{ACKNOWLEDGEMENTS}

This research was supported by grants from the Ministry of Education, Culture, Sports, Science and Technology, and a Research Grant for Nervous and Mental Disorders from the Ministry of Health, Labor and Welfare, Japan. We thank Prof Y Takai (Department of Molecular Biology and Biochemistry, Osaka University Medical School, Japan) for providing the anti-SAPAP1 antibody.

\section{REFERENCES}

American Psychiatric Association (1994). Diagnostic and Statistical Manual of Mental Disorders, 4th ed. American Psychiatric Press: Washington, DC.

Berrettini WH (2000). Are schizophrenic and bipolar disorders related? A review of family and molecular studies. Biol Psychiatry 48: 531-538.

Berrettini WH, Ferraro TN, Goldin LR, Weeks DE, DeteraWadleigh SD, Nurnberger Jr JI et al (1994). Chromosome 18 DNA markers and manic depressive illness: evidence for a susceptibility gene. Proc Natl Acad Sci USA 91: 5918-5921.

Cascella NG, Macciardi F, Cavallini C, Smeraldi E (1994). Dcycloserine adjuvant therapy to conventional neuroleptic treat- 
ment in schizophrenia: an open-label study. J Neural Transm 95: 105-111.

Chambers RA, Krystal JH, Self DW (2001). A neurobiological basis for substance abuse comorbidity in schizophrenia. Biol Psychiatry 50: 71-83.

Craven SE, Bredt DS (1998). PDZ proteins organize synaptic signaling pathways. Cell 93: 495-498.

Detera-Wadleigh SD, Badner JA, Berrettini WH, Yoshikawa T, Goldin LR, Turner G et al (1999). A high-density genome scan detects evidence for a bipolar susceptibility locus on 13q32 and other potential loci on 1q32 and 18p11.2. Proc Natl Acad Sci USA 96: 5604-5609.

Dracheva S, Marras SAE, Elhakem SL, Kramer FR, Davis KL, Haroutunian V (2001). N-methyl-D-aspartic acid receptor expression in the dorsolateral prefrontal cortex of elderly patients with schizophrenia. Am J Psychiatry 158: 1400-1410.

Gao X-M, Shirakawa O, Du F, Tamminga CA (1993). Delayed phencyclidine-induced alterations in local cerebral glucose utilization. Eur J Pharmacol 241: 7-15.

Gao X-M, Tamminga CA (1994). An increase NMDA-sensitive $\left[{ }^{3} \mathrm{H}\right]$ glutamate and $\left[{ }^{3} \mathrm{H}\right]$ kainate binding in hippocampus 24 hours after PCP. Neurosci Lett 174: 149-153.

Gao X-M, Tamminga CA (1996). Phencyclidine produces changes in NMDA and kainate receptor binding in rat hippocampus over a 48-hour time course. Synapse 23: 274-279.

Goff DC, Coyle JT (2001). The emerging role of glutamate in the pathophysiology and treatment of schizophrenia. Am J Psychiatry 158: 1367-1377.

Goff DC, Tsai G, Manoach DS, Coyle JT (1995). Dose-finding trial of D-cycloserine added to neuroleptics for negative symptoms in schizophrenia. Am J Psychiatry 152: 1213-1215.

Greifenstein FE, Yoshitake J, DeVault M, Gajewski JE (1958). A study of 1-aryl-cyclohexylamine for anesthesia. Anesth Analg 37: 283-294.

Heid CA, Stevens J, Livak LJ, Williams PM (1996). Real time quantitative PCR. Genome Res 6: 986-994.

Heresco-Levy U, Javitt DC, Ermilov M, Mordel C, Kelly D (1996). Double-blind, placebo-controlled crossover trial of glycine adjuvant therapy for treatment-resistant schizophrenia. $\mathrm{Br}$ Psychiatry 169: 610-617.

Javitt DC, Zukin SR (1991). Recent advances in the phencyclidine model of schizophrenia. Am J Psychiatry 148: 1301-1308.

Javitt DC, Zylberman I, Zukin SR, Heresco-Levy U, Lindenmayer J$P$ (1994). Amelioration of negative symptoms in schizophrenia by glycine. Am J Psychiatry 151: 1234-1236.

Kennedy MB (1998). Signal transduction molecules at the glutamatergic postsynaptic membrane. Brain Res Rev 26: 243257.

Kim E, Naisbitt S, Hsueh Y-P, Rao A, Rothschild A, Craig AM et al (1997). GKAP, a novel synaptic protein that interacts with the guanylate kinase-like domain of the PSD-95/SAP90 family of channel clustering molecules. J Cell Biol 136: 669-678.

Kornau H-C, Schenker LT, Kennedy MB, Seeburg PH (1995). Domain interaction between NMDA receptor subunits and the postsynaptic density protein PSD-95. Science 269: $1737-1740$.

Krystal JH, Karper LP, Seibyl JP, Freeman GK, Delaney R, Bremner JD et al (1994). Subanesthetic effects of the noncompetitive NMDA antagonist ketamine in humans: psychotomimetic perceptual cognitive and neuroendocrine responses. Arch Gen Psychiatry 51: 199-214.

Laemmli UK (1970). Cleavage of structural proteins during the assembly of the head of bacteriophage T4. Nature 227: 680-685.

Lahti AC, Holcomb HH, Medoff DR, Tamminga CA (2001). Ketamine activates psychosis and alters limbic blood flow in schizophrenia. Neuroreport 6: 869-872.

Lau L-F, Mammen A, Ehlers ME, Kindler S, Chung WJ, Garner CC et al (1996). Interaction of the $N$-methyl-D-aspartate receptor complex with a novel synapse-associated protein, SAP102. J Biol Chem 271: 21622-21628.

Leveque JC, Macias W, Rajadhyaksha A, Carlson RR, Barczak A, Kang S et al (2000). Intracellular modulation of NMDA receptor function by antipsychotic drugs. J Neurosci 20: 4011-4020.

Liang P, Pardee AB (1992). Differential display of eukaryotic messenger RNA by means of polymerase chain reaction. Science 257: 967-971.

Liang P, Pardee AB (1995). Recent advances in differential display. Curr Opin Immunol 7: 274-280.

Lowry OH, Rosebrough NJ, Farr AL, Randall RJ (1951). Protein measurement with the folin phenol reagent. J Biol Chem 193 153-159.

Luby ED, Gottlieb JS, Cohen BD, Rosenbaum G, Domino EF (1962). Model psychoses and schizophrenia. Am J Psychiatry 119: 61-67.

Malhotra AK, Pinals DA, Adler CM, Elman I, Clifton A, Pickar D et al (1997). Ketamine-induced exacerbation of psychotic symptoms and cognitive impairment in neuroleptic-free schizophrenics. Neuropsychopharmacology 17: 141-150.

Meador-Woodruff JH, Healy DJ (2000). Glutamate receptor expression in schizophrenic brain. Brain Res Rev 31: 288-294.

Meltzer HY, Holtzman PA, Hassan SZ, Guschwan A (1972). Effects of phencyclidine and stress on plasma CPK and aldolase activity in man. Psychopharmacology 26: 44-53.

Meyer JS, Greifenstein FE, DeVault M (1959). A new drug causing symptoms of sensory deprivation. J Nerv Ment Dis 129: $54-61$.

Naisbitt S, Kim E, Tu JC, Xiao B, Sala C, Valtschanoff J et al (1999). Shank, a novel family of postsynaptic density proteins that binds to the NMDA receptor/PSD-95/GKAP complex and cortactin. Neuron 23: 569-582.

Niethammer M, Kim E, Sheng M (1996). Interaction between the C-terminus of NMDA receptor subunits and multiple members of the PSD-95 family of membrane-associated guanylate kinases. J Neurosci 16: 2157-2163.

Nishino N, Noguchi-Kuno SA, Sugiyama T, Tanaka C (1986). $[3 \mathrm{H}]$ Nitrendipine binding sites are decreased in the substantia nigra and striatum of the brain from patients with Parkinson's disease. Brain Res 377: 186-189.

Nothen MM, Cichon S, Rohleder H, Hemmer S, Franzek E, Fritze J et al (1999). Evaluation of linkage of bipolar affective disorder to chromosome 18 in a sample of 57 German families. Mol Psychiatry 4: 76-84.

O’Brien RJ, Lau LF, Huganir RL (1998). Molecular mechanisms of glutamate receptor clustering at excitatory synapses. Curr Opin Neurobiol 8: 364-369.

O'Donnell P, Grace AA (1998). Phencyclidine interferes with the hippocampal gating of nucleus accumbens neuronal activity in vivo. Neuroscience 87: 823-830.

Ohnuma T, Kato H, Arai H, Faull RLM, McKenna PJ, Emson PC (2000). Gene expression of PSD95 in prefrontal cortex and hippocampus in schizophrenia. Neuroreport 11: 3133-3137.

Okuyama S, Ogawa S, Nakazato A, Tomizawa K (1995). Effect of NE-100, a novel sigma receptor ligand, on phencyclidineinduced delayed cognitive dysfunction in rats. Neurosci Lett 189: 60-62.

Olney JW, Labruyere J, Price MT (1989). Pathological changes induced in cerebrocortical neurons by phencyclidine and related drugs. Science 244: 1360-1362.

Palkovits M (1973). Isolated removal of hipothalamal or other brain nuclei of the rat. Brain Res 59: 449-450.

Rosse RB, Fay-McCarthy M, Kendrick K, Davis RE, Deutsch SI (1996). D-cycloserine adjuvant therapy to molindone in the treatment of schizophrenia. Clin Neuropharmacology 19: 444450.

Satoh K, Yanai H, Senda T, Kohu K, Nakamura T, Okumura N et al (1997). DAP-1, a novel protein that interacts with the guanylate 
kinase-like domains of hDLG and PSD-95. Genes Cells 2: 415424.

Scannevin RH, Huganir RL (2000). Postsynaptic organization and regulation of excitatory synapses. Nat Rev 1: 133-141.

Schwab SG, Hallmayer J, Lerer B, Albus M, Borrmann M, Hönig S et al (1998). Support for a chromosome 18p locus conferring susceptibility to functional psychoses in families with schizophrenia, by association and linkage analysis. Am J Hum Genet 63: 1139-1152.

Sheng M, Wyszynski M (1997). Ion channel targeting in neurons. Bioessays 19: 847-853.

Stine OC, Xu J, Koskela R, McMahon FJ, Geschwend M, Friddle C et al (1995). Evidence for linkage of bipolar disorder to chromosome 18 with a parent-of-origin effect. Am J Hum Genet 57: 1384-1394.

Takeuchi M, Hata Y, Hirao K, Toyoda A, Irie M, Takai Y (1997). SAPAPs: a family of PSD-95/SAP90-associated proteins localized at postsynaptic density. J Biol Chem 272: 11943-11951.

Tamminga CA (1998). Schizophrenia and glutamatergic transmission. Crit Rev Neurobiol 12: 21-36.
Tu JC, Xiao B, Naisbitt S, Yuan JP, Petralia RS, Brakeman P et al (1999). Coupling of mGluR/Homer and PSD-95 complexes by the Shank family of postsynaptic density proteins. Neuron 23: 583-592.

Yamamoto BK, Cooperman MA (1994). Differential effects of chronic antipsychotic drug treatment on extracellular glutamate and dopamine concentrations. J Neurosci 14: 4159-4166.

Yao I, Hata Y, Hirao K, Deguchi M, Ide N, Takeuchi M et al (1999). Synamon, a novel neuronal protein interacting with synapseassociated protein 90/postsynaptic density-95-associated protein. J Biol Chem 274: 27463-27466.

Yoshikawa T, Sanders AR, Esterling LE, Overhauser J, Garnes JA, Lennon $\mathrm{G}$ et al (1997). Isolation of chromosome 18-specific brain transcripts as positional candidates for bipolar disorder. Am J Med Genet 74: 140-149.

Wessinger WD, Owens SM (1991). Phencyclidine dependence: the relationship of dose and serum concentrations to operant behavioral effects. J Pharmacol Exp Ther 258: 207-215.

Ziff EB (1997). Enlightening the postsynaptic density. Neuron 19: 1163-1174. 